brittle books and U.S. newspapers being preserved on microfilm has been substantially reduced. The proposed budget would enable the NEH to reverse these conditions.

Our budget request uses two basic approaches to address the nation's educational and cultural wellbeing-maintain and enhance NEH's core programs and establish new initiatives that reach out to the American pubiic. Both of these approaches are vital to the health of the humanities as our nation enters the twenty-first century.

The Endowment's budget request places particular emphasis on the educational mission of our agency. Our goal is to advance knowledge and understanding of the humanities for all Americans. Central to achieving this goal is placing a strong emphasis on teaching and learning at all levels of our nation's educational system. We will focus on the professional development of humanities teachers at elementary and secondary schools and at colleges and universities. And we will continue to use MCI WorldCom's generous support to develop the nation's premier Internet resource for humanities teachers, EDSITEment (http:// edsitement.neh.gov/), which provides links to and lesson plans for 50 topquality humanities web sites. We will also enhance the Endowment's recently launched Schoolsfor a New Millennium, and initiative through which schools form partnerships with local libraries, museums, and universities to establish a communitywide learning environment that incorporates new technology support to teach the humanities.

The Endowment supports a wide range of educational projects that include teacher seminars and institutes that improve teaching and learning of the humanities in the traditional classroom setting; public edcuation programs of the 56 state humanities councils; documentary television films, museum exhibitions, library reading groups, and other general-audience projects that help out-of-school citizens engage in a lifetime of learning; projects that preserve and increase access to endangered educational and intellectual materials; and serious research and scholarship that both contrib-

\section{Washington Insider}

\section{Wilson Center Focuses on Making Research Relevant}

New Woodrow Wilson Center International Center for Scholars Director Lee Hamilton wants to make the Center "a place where visiting heads of state and dignitaries come regularly to say what they want to say about their policy positions." Established by Congress in 1968 as the nation's official memorial to the twenty-eighth U.S. president (and sixth APSA president), the Center was founded to bridge the physical and intellectual gaps among academics and policymakers. Hamilton, a sixterm Democratic representative to Congress from Indiana and the first nonacademic to head the Center, has emphasized that the programs and projects he has initiated merely fulfill the Center's original mission. Critics of the new emphasis on "relevance" and "influence," who include some former fellows, worry that the long-time haven for champions and practitioners of learning for learning's sake will become "just another" Washington think tank under Hamilton. Recent projects have included sponsorship of informal diplomatic talks between the Mexican government and Chiapas rebels and encouragement of dialog between American and Iranian officials. To ensure the recruitment of fellows able and willing to play a more active role, applicants are now required to demonstrate the relevance of their proposed study to a contemporary issue and efforts have been made to attract economists, political scientists and anthropologists in addition to the historians who comprise a majority of each fellowship group. A long-standing commitment to attract non-U.S. scholars also continues. More information about the Center, its activities, and how to apply for a fellowship can be found online at wwics.si.edu.

\section{Digital Database Copyright Bill Reintroduced}

Rep. Howard Coble (R-NC), chair of the House Subcommittee on Courts and Intellectual Property, introduced the "Collection of Information Antipiracy Act" (H.R. 354) to Congress on January 19. Very similar in content and intent to a bill by the same name the House passed and the Senate shelved late in 1998, Coble's bill stipulates that "any person who extracts, or uses in commerce, all or a substantial part . . . of a collection of information gathered, organized, or maintained by another person . so as to cause harm to the actual or potential market of that other person" will face punishments ranging from the payment of monetary damages to serving five years in jail. Coble, working with fellow Representative Howard Berman (D-CA) and Senators Patrick Leahy (D-VT) and Orrin Hatch (R-UT), has reintroduced the legislation "to protect developers ... against piracy and unfair competition, and thus encourage continued investment in the production and distribution of valuable commercial collections of information." If passed, it would preempt all existing state laws, extend federal control over electronic commerce, and provide protections separate from and in addition to those provided by "patent, trademark, design rights, antitrust, trade secrets, privacy, access to public documents, and the law of contract."

During a mid-March hearing before the intellectual property subcommittee, representatives of the U.S. Copyright Office and the federal Department of Commerce expressed the executive branch's support for the bill. In the same hearing, representatives of the major U.S. library and college and university associations detailed their problems with the current bill, focusing particularly on the control database compilers would have over the access to and distribution of information if the bill became law and the weakness and ambiguity of the bill's "fair use" provisions.

"Collections of information" are defined in the bill as "information that has been collected and has been organized for the purpose of bringing discrete items of information together in one place . . . so that users may access them." As the term is used in the bill, "collections of information" are primarily electronic databases like the one maintained by ICPSR and the individual data sets stored therein, but also directories, catalogs, genealogical registries, and medical diagnostic guides. The definition might also apply to bound code sheets or entire libraries.

The bill is designed only to protect database developers from losses caused by other parties copying and selling their products. Very broad exceptions are drawn for students', researchers', and reporters' one-time use of information taken from proprietary databases, although "repeated or systematic extraction" is prohibited except through a licensing agreement. Additionally, the current bill proposes lifting all copying and distribution restrictions after 15 years from the date of initial creation. No mention is made of how creation or ownership of collections of information would be registered or recorded or whether additions or corrections to existing collections would constitute creations of new collections.

\section{Important Washington People}

Bruce Alberts, has been reelected president of the National Academy of Sciences. His second six-year term will begin in July of this year. Joseph Bordogna, acting deputy director of the National Science Foundation, has been nominated to become full-time deputy director of the Foundation. 